\author{
Anna Bednarczyk \\ Uniwersytet Łódzki \\ anbednar@02.pl
}

\title{
IZABELLA GRINIEWSKA* JAKO TŁUMACZKA POEZJI POLSKIEJ W KONTEKŚCIE DOMINANT EPOKI SREBRNEGO WIEKU
}

DOl: http://dx.doi.org/10.12775/RP.2017.001

\begin{abstract}
Zarys treści: W artykule analizowane są przekłady polskiej poezji dokonane przez Izabellę Griniewską, która tworzyła na przełomie XIX i XX stulecia. Jej tłumaczenia zostały rozpatrzone w kontekście dominant literackich srebrnego wieku oraz obowiązujących w tym czasie zasad tłumaczenia i ścierających się poglądów na ten temat. Pod uwagę wzięto również religijne i filozoficzne zainteresowania tłumaczki, mające wpływ na jej wybory translatorskie. Dokonano również próby prezentacji sztuki translatorskiej Griniewskiej niezależnie od epoki, w jakiej tworzyła, jako jednego z ogniw łańcucha badań traduktologicznych.
\end{abstract}

Słowa kluczowe: Izabella Griniewska, srebrny wiek, tłumaczenie, poezja

\section{Kilka słów o Izabelli Griniewskiej}

zabella Griniewska, córka orientalisty Abrahama Szaloma Frydberga, przyszła na świat 3 (15) maja 1854 lub 1864 roku w Grodnie. Po ukończeniu gimnazjum w latach 80. XIX stulecia wyjechała do Petersburga, gdzie kształciła się na Wyższych Kursach dla Kobiet im. Bestużewa-Riumina. W 1942 roku, zmarła z głodu podczas blokady Leningradu.

* W tekście użyto normatywnej współcześnie formy nazwiska Griniewska, chociaż np. w pracy Haliny Rarot pojawił się zapis Gryniewska (Rarot 2012: 172-179). 
Elena Leonienko $\mathrm{w}$ uzasadnieniu do planowanej przez siebie rozprawy doktorskiej o życiu i twórczości Griniewskiej pisze, że informacje o tej prawie zapomnianej dzisiaj poetce, dramatopisarce, dziennikarce oraz tłumaczce wymagają potwierdzenia i uzupełnienia, ponieważ są niepełne i niepewne (Леоненко 2015: online). Rozmaite źródła podają inne daty urodzin, różne daty przybycia Griniewskiej do Petersburga, a wątpliwości - o czym pisze Leonienko - dotyczą też daty jej śmierci (1942 albo 1944 rok). Odnotujmy, że na anglojęzycznej stronie Wikipedii znajdziemy nawet informację, że Griniewska zmarła w 1944 roku w Istambule (Wikipedia: online). Co więcej, podobno brakuje wiarygodnego potwierdzenia, że jej ojcem był Frydberg, a pewna nie jest również podawana $\mathrm{w}$ niektórych źródłach informacja, że Griniewska była ciotką pisarza Aleksandra Grina (Варламов 2008: online). Poza tym prawie nic nie wiadomo na temat jej działalności twórczej po rewolucji październikowej. Zwykle wskazuje się na publikację ostatniej książki poetki - zbioru wierszy Павловск w 1922 roku. Mówi się też o jej przekładach, pracy dydaktycznej i o tym, że mimo oficjalnego uznania bahaizmu za religię zakazaną w ZSRR, adres Griniewskiej do końca jej życia podawano we wszystkich bahaistycznych informatorach jako adres kontaktowy na terenie Rosji, o czym wspomina np. Jekatierina Kolcowa-Cariewa ${ }^{1}$ (КольцоваЦарева 2015: online).

To ostatnie zapewne wynikało z faktu, że Griniewska była najbardziej znana jako autorka dwu dramatów historycznych, Bab (Баб 1903) i Bahaullah (Беха-Улла 1912), poświęconych założycielom współczesnych ruchów religijnych - babizmu oraz bahaizmu, którego wyznawczynią została.

Warto przy tym wspomnieć, że nie znając zasad owych ruchów i wiedzy na temat obowiązującego w nich zakazu ukazywania na scenie założycieli religii, Griniewska uczyniła z Baba i z Bahaullaha bohaterów swoich sztuk. Sam Abdul-Baha (syn Bahaullaha) udzielił jednak zgody na wystawianie jej sztuk na scenie, a także na ich przekład na inne języki.

Griniewska była nie tylko dramaturgiem; oprócz sztuk publikowała również opowiadania, wiersze, artykuły prasowe, w tym krytyczne, współpracowała z redakcją Stownika encyklopedycznego Brockhausa i Efrona (Энииклопедический словарь Брокгауза и Ефрона), który był pierwszą rosyjską encyklopedią powszechną. Dla Słownika... napisała kilka haseł dotyczących literatury włoskiej i polskiej. Jej jednoaktówki wystawiano w teatrach rosyjskich, a ona sama - jako ich autorka - występowała na scenie pod pseudonimem Tamarina. Wykładała też sztukę sceniczną oraz deklamację.

1 Pseudonim literacki Jekatieriny Wiktorowny Cariewej. 
Po rewolucji 1917 roku, jak już wspomniano, została wydana tylko jedna książka Griniewskiej - tom wierszy. W Internecie można też znaleźć fragment jej zarchiwizowanych, niepublikowanych dotąd wspomnień (Гриневская 1900-1902: online). Poza tym wiadomo, że jako tłumaczka Griniewska współpracowała z wydawnictwem Wsiemirnaja Litieratura. Wróciła więc do tego, od czego rozpoczęła swą działalność literacką.

Wypada także zauważyć, że Griniewska znała kilka języków; pierwsze jej utwory powstały w języku polskim, a tłumaczyła na rosyjski z polskiego, angielskiego, niemieckiego, włoskiego i francuskiego.

Spośród polskich poetów przekładała wiersze: Adama Mickiewicza, Teofila Lenartowicza, Adama Asnyka, Kazimierza Przerwy-Tetmajera, Lucjana Rydla i Artura Oppmana (Or-Ota), a więc począwszy od największego polskiego romantyka, poprzez późnych reprezentantów tego nurtu w literaturze: Lenartowicza i Asnyka, aż po neoromantyków Młodej Polski.

Tłumaczka znała język polski i polską literaturę, a kształcąc się i mieszkając w Petersburgu, poznała nie tylko popularne w tym czasie nurty poetyckie, ale także pisarzy i poetów związanych przede wszystkim z symbolizmem i akmeizmem. Ponadto jej zainteresowania filozofią Wschodu przyczyniły się do pojawienia się szczególnego rodzaju romantyzmu, który uwidocznił się w jej twórczości. W autoreferacie rozprawy doktorskiej tak pisała o tym Elena Czacz:

Романтизация Востока и его противопоставление Западу, присущие Белому и Бальмонту, красной нитью проходят через творчество Изабеллы Аркадьевны Гриневской [...] В творчестве Гриневской можно наблюдать ориентализм в самом различном понимании этого термина. Во-первых, это увлечение Востоком и его романтизация, причем предметом для увлечения является «классический» персидский Восток. [...] Такой поворот отношения к Персии необычайно интересен и представляет собой своеобразное развитие линии классического ориентализма в соответствии с общими духовными поисками Серебряного века ${ }^{2}$ (Чач 2012: online).

2 „Charakterystyczna dla Biełego i Balmonta romantyzacja Wschodu oraz jego przeciwstawienie Zachodowi przenikają całą twórczość Izabelli Arkadiewny Griniewskiej. [...] W twórczości Griniewskiej można zauważyć orientalizm w najróżniejszym rozumieniu tego terminu. Po pierwsze chodzi o zainteresowanie Wschodem oraz jego romantyzacja, przy tym przedmiotem zainteresowania stał się „klasyczny” perski Wschód. [...] Takie ukierunkowanie na Persję jest niezwykle interesujące i jawi się jako swoisty rozwój linii klasycznego orientalizmu zgodne z całokształtem duchowych poszukiwań srebrnego wieku"; To i kolejne tłumaczenia cytatów moje - A.B. 
Romantyzm ten niewątpliwie wyraził się również w tłumaczeniach jej autorstwa, co spróbujemy prześledzić na przykładzie niektórych z nich. Podejmując taką próbę, warto odnieść się też do epoki, w jakiej dokonano przekładów, szczególnie uwzględniając dominujące w tym czasie zasady tłumaczenia.

\section{Czas przekładu}

Koniec XIX, a przede wszystkim początek XX wieku to czas, kiedy w Rosji i Związku Radzieckim pojawiło się wiele tłumaczeń z różnych języków. Ta uwaga dotyczy zarówno dzieł literatury światowej, jak i literatury narodów zamieszkujących ZSRR. W 1919 roku powstało też wspomniane wcześniej wydawnictwo Wsiemirnaja Literatura, które zajmowało się publikacją literatury światowej. Współpracowali z nim znani pisarze i poeci, tacy jak Aleksandr Błok, Maksym Gorki, Jewgienij Zamiatin czy Nikołaj Gumilow, a także znawcy sztuki translatorskiej, np. Korniej Czukowski oraz Michaił Łoziński. Tworzyli oni zręby ówczesnej rosyjskiej teorii tłumaczenia i w oparciu o nią proponowali własne przekłady. Rozpatrując sztukę translacji z początku XX wieku, nie można więc pominąć ani ich badawczej, ani przekładowej działalności, jak również wpływu na innych tłumaczy. W niniejszym studium nie będziemy jednak omawiać propozycji i sporów teoretycznych. Zauważymy tylko, że postulaty dosłowności oraz „wierności” translatorskiej rozumianej w różny sposób, często jako wierność formalna, ścierają się i wymieniają z koncepcją tłumaczenia twórczego (wolnego), o czym swego czasu pisał Michaił Gasparow w artykule o metodzie przekładowej Walerego Briusowa (Гаспаров 1971: 90-128) czy we wstępie do zbioru przekładów Siergieja Szerwińskiego:

Перевод всегда существует на грани двух поэтик. Он равнодействующая двух сил: художественного языка подлинника и родного художественного языка. Грубее говоря, это всегда насилие или языка подлинника над родным, или родного языка над подлинником. [...] В истории культуры эти два типа перевода чередуются ${ }^{3}$ (Гаспаров 2000: 4).

3 „Przekład zawsze znajduje się na granicy dwóch poetyk: Jest wypadkową dwóch sił: języka literatury pięknej oryginału i języka literatury pięknej przekładu. Mówiąc wprost, zawsze sprowadza się do przemocy języka oryginału nad językiem tłumaczenia, albo języka tłumaczenia nad językiem oryginału. [...] W historii kultury te dwa rodzaje przekładu występują wymiennie”. 
Podkreślają to w swoich pracach także współcześni autorzy, na przykład Andriej Azow czy Wiktor Łanczikow. Ten ostatni wyraźnie wskazuje na rolę wydawnictwa Wsiemirnaja Litieratura w budowaniu rosyjskiej szkoły tłumaczenia (Азов 2012: 131-134; Ланчиков 2009: 163-172).

Zauważmy przy tym, że przekład wolny w pewnym stopniu przypomina tłumaczenie romantyczne. Trzeba tu przypomnieć tę jego charakterystyczną cechę, jaką była koncepcja odtworzenia idei danego dzieła środkami wybranymi przez tłumacza - tymi, które uzna on za najlepsze. Ta cecha translacji uprawianej przez rosyjskich twórców, często uznanych poetów, okaże się niezwykle trwała. Prawdopodobnie także dlatego, że podobnie jak w czasach romantyzmu tłumaczenia podejmowali się najbardziej znani rosyjscy poeci, których przekłady zwykle przejmowały cechy ich własnej, oryginalnej twórczości.

„Strategia” ta była i do tej pory jest akceptowana przez krytykę, a tym bardziej przez czytelnika, ponieważ proponowane przez jej zwolenników teksty przekładowe zwykle prezentują wysoki poziom artystyczny. Pogląd o wartości takiego właśnie modelu translacji wyrażają tak cenieni rosyjscy teoretycy tłumaczenia jak Giwi Gaczeciładze, który twierdził, że:

На практике переводы часто отходят от текстуальной близости, чтобы приблизится в художественном отношении ${ }^{4}$ (Гачечиладзе 1973: 109).

Świadczą o tym również niezwykle rzadkie wypowiedzi krytyczne w stosunku do tłumaczeń autorstwa uznanych literatów, wskazujące na ich odejście od oryginału na rzecz trawestacji. W tym miejscu za przykład posłuży nam przekładowa twórczość znanego pisarza, poety, a zarazem tłumacza Borysa Pasternaka i wypowiedź Jurija Lifszyca, który rozpatrując rosyjski wariant jednego z wierszy Nikołoza Baratiszwili, pisał:

До сих пор никому из русских критиков как-то не приходило в голову сравнить оригинал Синего ивета с его переводом. Причин этому, на мой взгляд, по крайней мере, три. Первая: гениальность пастернаковского текста, к которому и придираться не хочется. Вторая - нежелание профессиональных литературоведов портить себе репутацию критикой отечественного классика $[\ldots]^{5}$ (Лифшиц: online).

4 „W praktyce, dobre tłumaczenia często odbiegają od wierności tekstowi na rzecz zbliżenia w wymiarze artystycznym ?"

${ }^{5}$ „Do tej pory nikomu z rosyjskich krytyków nie przyszło do głowy porównywanie ory- 
Z kolei cytowany przez Annę Siergiejewą-Kliatis gruziński poeta symbolista Walerian Gaprindaszwili konstatował w 1936 roku:

Пастернак пишет не копию, а портрет оригинала. Вы смотрите на двойника и [...] вы благодарны волшебнику, который ввёл вас в ином уборе в [...] мир русской поэзии ${ }^{6}$ (Сергеева-Клятис 2005: online).

Wreszcie przytoczmy za Siergiejewą-Kliatis słowa samego Pasternaka, który w następujący sposób odniósł się do swojej pracy nad wierszami Barataszwili:

Из этого надо сделать русские стихи, как я делал из Шекспира, Шевченки, Верлена и других, так я понимаю свою задачуㄱ (Сергеева-Клятис 2005: online).

Można więc przychylić się do zdania Swietłany Stiepury, która stwierdza:

... можно сделать вывод, что переводчики 20-30-х гг. XX века [...] полагались на определенные тенденции, существовавшие в то время в литературе и на свои личные предпочтения в этой области. Таким образом, 1920-1930е годы, так или иначе, связаны с переводческим буквализмом, которому на смену приходит творческое отношение к переводу оригинального текста уже в конце 1930-х гг. [...] оба подхода к переводу существовали параллельно и в указанный период и до, и после него ${ }^{8}$ (Степура 2011: online).

Interesująca nas jako tłumaczka Izabella Griniewska przekładała, o czym już wspomniano, z różnych języków, jednak tłumaczenia z języka polskiego są dla nas szczególnie interesujące. Nie tylko dlatego, że polski jest naszym

ginału Синего иявета z jego przekładem. Przyczyny są moim zdaniem co najmniej trzy. Po pierwsze - geniusz Pasternakowego tekstu, do którego nikomu nieśpieszno się czepiać. Po drugie - niechęć profesjonalnych literaturoznawców do psucia własnej reputacji w związku krytyką ojczystego klasyka”.

${ }^{6}$ „Pasternak nie maluje kopii, ale portret oryginału. Widzisz swój sobowtór i [...] jesteś wdzięczny czarownikowi, który wprowadził cię w innej szacie do [...] świata poezji rosyjskiej”.

7 „Z tego trzeba zrobić rosyjskie wiersze, jak to robiłem z Szekspirem, Szewczenką, Verlainem i innymi, tak rozumiałem swoje zadanie".

${ }^{8}$ „... można uznać, że tłumacze $\mathrm{z}$ lat 20-30 XX w, [...] stosowali się do popularnych w tym czasie w literaturze tendencji, a jednocześnie do swoich własnych przekonań w tym względzie. A więc lata 1920-1930 w taki czy inny sposób związane były z translatorską dosłownością, którą już pod koniec 1930 zastąpił twórczy stosunek do przekładu [...] oba podejścia do tłumaczenia istniały równolegle zarówno we wskazanym czasie, jak i wcześniej, a także później”. 
językiem ojczystym, ale również z tego względu, że początek działalności literackiej tej autorki wiąże się właśnie z tym językiem. Poza przekładami były to pisane po polsku wiersze.

Dokonując próby analizy przyjętej przez Griniewską strategii przekładowej, którą - modyfikując nieco słowa Barbary Kielar o „świadomych działaniach skierowanych na osiągnięcie celu” (Kielar 1988: 17) i „potencjalnie świadomych planach" tłumacza (Kielar 1988: 30) - uznaję za wyraz potencjalnie uświadamianych celów tłumacza, trzeba uwzględnić tę okoliczność. Wnika z niej bowiem, że wszelkie odstępstwa od oryginału winny być traktowane jako manipulacja jego tekstem w celu realizacji pewnej strategii, zgodnie ze słowami Theo Hermansa:

...from the point of view of target literature, all translation implies a degree of manipulation of the source text for a certain purpose ${ }^{9}$ (Hermans 1985: 11).

oraz konstatacją Andreégo Lefevere’a, który wskazywał na różnice między błędem a świadomą manipulacją: „Translators make mistakes only on the linguistic level. The rest is strategy"10 (Lefevere 1983: 74). Dlatego też winniśmy traktować owe odstępstwa jak realizację jednej z dwu ścierających się strategii, w tym przypadku jako tłumaczenie twórcze, które przyzwalało na stosunkowo dużą swobodę translacji.

\section{Sztuka przekładu}

Jako przykład posłużą nam wiersze kilku polskich autorów, które zostały dobrane chronologiczne. Będą to: Polały się łzy me czyste... Adama Mickiewicza, Rosła kalina Teofila Lenartowicza, motto do Na skalnym Podhalu Kazimierza Przerwy-Tetmajera i dwa teksty Adama Asnyka - Idź dalej... oraz Dwie fazy. Pozwoli to przyjrzeć się postępowaniu Griniewskiej z tekstami autorstwa przedstawicieli różnych epok literackich.

Rozpoczniemy od utworu największego z tłumaczonych przez Griniewską polskich romantyków, Mickiewicza. Interesujący nas wiersz jest niezwykle interesujący z punktu widzenia wersyfikacji, o czym swego czasu pisał Julian Przyboś: „nie jest to ani wiersz sylabiczny, ani sylabotoniczny, ani to-

${ }^{9}[\ldots]$ z punktu widzenia literatury w języku docelowym wszelki przekład implikuje jakiś stopień manipulacji tekstem źródłowym dla osiągnięcia pewnych celów.

10 Tłumacz popełnia błędy jedynie na poziomie lingwistycznym. Reszta jest strategią. 
niczny” (Przyboś 1998: 212) ${ }^{11}$, który też uważał go za „jeden z najbardziej nowatorskich wierszy w języku polskim” (Przyboś 1998: 208). A jednak rosyjska tłumaczka czyni z niego typowy dla poezji rosyjskiej sylabotonik - hiperkatalektyczny czterostopowy amfibrach:

\section{Ли-лись мо-и сле-зы ро-сис-ты-е, чис-ты-е}

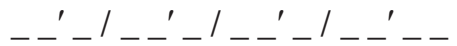

System rymów w obu wariantach jest taki sam. Zostało też zachowane zamykające wiersz powtórzenie pierwszej strofy: „Polały się łzy me czyste, rzęsiste” - „Лились мои слезы росистые, чистые”. Nie udało się natomiast zachować powtarzającego się aliteracyjnie w kolejnych wersach: „Na me dzieciństwo...”, „Na moją młodość...”, „Na mój wiek męski...”. Tego powtórzenia zabrakło w wersie odnoszącym się do młodych lat. Można więc mówić o częściowym odtworzeniu formalnych cech polskiego utworu i o zaadaptowaniu go do rosyjskiej tradycji wiersza sylabotonicznego.

\begin{tabular}{|l|l|}
\hline \multicolumn{1}{|c|}{$\begin{array}{c}\text { Adam Mickiewicz } \\
\text { Polały się tzy me czyste... }\end{array}$} & \multicolumn{1}{c|}{$\begin{array}{c}\text { Izabella Griniewska } \\
\text { Слезы (Łzy) }\end{array}$} \\
\hline $\begin{array}{l}\text { Polały się łzy me czyste, rzęsiste } \\
\text { Na me dzieciństwo sielskie, anielskie, }\end{array}$ & Лились мои слезы росистые, чистые \\
Na moją młodość górną i durną, & Одетстведалеком игривом, счастливом, \\
Na mój wiek męski, wiek klęski; & Изменчивой юности бравой, туманной; \\
Polały się łzy me czyste, rzęsiste... & О зрелости годах унылых, постылых \\
(Mickiewicz: online) & Лились мои слезы росистые, чистые* \\
\hline
\end{tabular}

Z kolei rozpatrując płaszczyznę semantyczną utworu, warto zwrócić uwagę na zastąpienie „sielskiego, anielskiego” dzieciństwa dzieciństwem „dalekim, swawolnym i szczęśliwym” (далекое, игривое, счастливое); przeobrażenie młodości, która z „górnej i durnej” stała się zmienną, odważną/ dziarską i zamgloną/marzycielską (изменчивая, бравая, туманная), oraz na to, jak wiek męski z „wieku klęski” zmienił się w lata złe/smutne i niemiłe (унылые, постылые). Niemniej są to zmiany na poziomie mikrotekstu, nie muszą powodować przesunięć w skali makro i raczej ich nie powodują. Dzieciństwo pozostaje radosne, młodość jest czasem buntów i marzeń. Najpoważniejsza transformacja dotyczy lat dojrzałych. Są one wprawdzie złe, smutne, niemiłe, ale nie zostały określone mianem klęski (фиаско, поражение,

* Wszystkie tłumaczenia Griniewskiej pochodzą ze strony internetowej „Век преревода”.

11 Pierwsze wydanie 1950. 
бедствие). Złagodzono więc słowa polskiego poety. Najprawdopodobniej jednak nie dlatego, że Griniewska chciała zmiany semantycznej, ale z powodu konieczności utworzenia rymu wewnętrznego.

Kolejny interesujący nas tekst jest przykładem o wiele poważniejszych modyfikacji poetyckich. Idzie tu mianowicie o wiersz Иду я с ношею..., którego pierwowzorem jest najprawdopodobniej Idź dalej... Adama Asnyka (Asnyk, tłum. Griniewska: online; Asnyk: online). Najprawdopodobniej, ponieważ „przekład” bardzo odbiega od oryginału. W tym przypadku Griniewska również buduje wiersz sylabotoniczny, wydłuża jednak trójstopowy amfibrach Asnyka do sześciostopowego hiperkatalektycznego jambu ze średniówką po szóstej sylabie:

Wzy-wa-łem ciem-no-ści: niech wsta-nie!

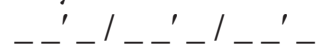

И-ду я с но-ше-ю... Тру-дна мо-я до-ро-га

- ${ }_{-}$' _

Taka forma wiersza prowadzi do wyraźnego zatarcia dynamiki polskiego wariantu. Na tym jednak nie kończą się różnice między dwiema wersjami tekstu. Wiersz rosyjski jest też dłuższy od polskiego o jedną strofę, a jego wersy, poza „rozrostem” z 9 do 13 sylab, zyskały dodatkowe elementy, przede wszystkim amplifikacje rozszerzające obrazy poetyckie. Jeśli podmiot liryczny Asnyka w strofie pierwszej mówi:

Wzywałem ciemności: niech wstanie!

I niech mnie pogrąży w noc ciemną -

Wzywałem milczące otchłanie,

By łona zawarły nade mną. -,

to podmiot wiersza Griniewskiej idzie, dźwigając ciężar: „Иду я с ношею”, jego droga do domu jest trudna i daleka: „Трудна моя дорога”, „Далеко мне идти до отчего порога", a pozbawiona radości noc ciągnie się: „И долго тянется безрадостная ночь” і nie ma już siły dźwigać swego ciężaru: „И ношу волочить мне более невмочь”. W kolejnej zwrotce liryczne „ja” polskiego poety wzywa „strasznego anioła”, by ten zatarł jego ślady na ziemi i pogrążył jego życie w niepamięci. Wszystko to zobaczymy też w rosyjskim wariancie, ale tłumaczka "rozciągnęła” wołanie podmiotu lirycznego na dwie strofy i zastosowała liczne transpozycje. Znajdziemy tu pustkę, która 
ma się rozstąpić, odpowiednik ciemności i „milczących otchłani” z pierwszej zwrotki, a także wołanie do nocy i mgły, by się nad nim zamknęły:

О, бездна, расступись! глубокая, немая,

И в тайниках твоих навек меня зарой!

O, тьма, ночная тьма, моей мольбе внимая,

Заботливо меня ты пологом укрой!

Potem pojawi się też mroczny anioł, który z powodzeniem zastępuje polskiego - „strasznego”, ale nie jest on tylko mroczny, lecz także współczujący i mocarny („сумрачный, всеблагий и могучий”). Anioł ten skrzydłem zmiecie z ziemi ślad podmiotu lirycznego („Мой след с лица земли крылом своим сметет”). Griniewska przywołuje też obraz nieprzebytego lasu i rzeki niepamięci, które ogarną świat lirycznego „ja”.

Пусть ангел сумрачный, всеблагий и могучий

Мой след с лица земли крылом своим сметет...

Где я блуждал когда - пусть лес взойдет дремучий,

Река забвения пускай там потечет.

W taki sposób do oryginalnego obrazu dodano „wzmacniające” obraz rozpaczy elementy, choćby takie jak porastający wszystko las czy rzeka niepamięci, które czytelnik może kojarzyć z mitologią grecką (rzeka niepamięci - Lete), ale też np. ze znanym wierszem Osipa Mandelsztama z 1920 roku, pt. Возьми на радость из моих ладоней..., gdzie pojawił się nieobeszły (nieprzebyty) las („дремучий лес Тайгета”).

Niezależnie od pewnych różnic najbardziej zbliżone są do siebie strofy wieńczące obie wersje językowe:

\begin{tabular}{|l|l|}
\hline \multicolumn{1}{|c|}{\begin{tabular}{c}
\multicolumn{1}{|c|}{ Adam Asnyk } \\
Idź dalej...
\end{tabular}} & \multicolumn{1}{|c|}{\begin{tabular}{c}
\multicolumn{1}{|c|}{ Izabella Griniewska } \\
Иду $\boldsymbol{c}$ ношею...
\end{tabular}} \\
\hline $\begin{array}{l}\text { Lecz próżno wzywałem litości, } \\
\text { Jak inni przede mną wzywali... } \\
\text { Głos tylko mnie doszedł z ciemności, } \\
\text { Co wołał: „Idź dalej, idź dalej!” }\end{array}$ & $\begin{array}{l}\text { Напрасны все мечты. Напрасно все мо- } \\
\text { ленья } \\
\text { Несутся к небесам из трепетной груди - } \\
\text { Из дали слышится мне слово повеленья: } \\
\text { „Вперед, вперед иди...” }\end{array}$ \\
\hline Tłum. filologiczne: & $\begin{array}{l}\text { Próżne wszelkie marzenia. Próżne wszystkie } \\
\text { modlitwy } \\
\text { Niosą się w niebo z drżącej piersi - } \\
\text { Z oddali słyszę słowa rozkazu: } \\
\text { „Naprzód, idź naprzód...” }\end{array}$ \\
\hline
\end{tabular}


Jednak także tu zauważamy amplifikacje i substytucje: niosące się do niebios marzenia i modlitwy w miejsce litości, drżąca pierś, słyszane z oddali słowa rozkazu zamiast głosu z ciemności, a ponadto powtórzenia leksykalne („Напрасны все...”, „Напрасно все...” oraz „Вперед, вперед”).

Podobną strategię stosuje Griniewska także w innych tłumaczeniach. Można w nich zaobserwować rozszerzenia polegające na wprowadzeniu dodatkowych epitetów. Dobrym przykładem są Dwie fazy Asnyka. Zaprezentujmy w tym miejscu kilka pochodzących z nich wersów i ich odpowiedników $\mathrm{z}$ wersji rosyjskiej:

\begin{tabular}{|c|c|}
\hline $\begin{array}{c}\text { Adam Asnyk } \\
\text { Dwie fazy }\end{array}$ & $\begin{array}{c}\text { Izabella Griniewska } \\
\text { Две фазы }\end{array}$ \\
\hline $\begin{array}{l}\text { Kiedy myśl wielka nagle zajaśnieje } \\
\text { I porwie z sobą mętną ludzi falę } \\
\text { Burzliwym prądem niosąc ją przez dzieje } \\
\text { Ku szczęściu, prawdzie, zwycięstwu i chwa- } \\
\text { le, } \\
\text { Wtenczas pierś każda ludzka olbrzymieje } \\
\text { (Asnyk online) }\end{array}$ & $\begin{array}{l}\text { Когда, как солнце, мысль над миром за- } \\
\text { горится } \\
\text { Людская сонная и мутная волна } \\
\text { В поток стремительный мгновенно за- } \\
\text { клубится } \\
\text { И в даль заветную уносится она. } \\
\text { Душа тогда, как вихрь, над бездной гордо } \\
\text { мчится } \\
\text { (Asnyk, tłum. Griniewska online) }\end{array}$ \\
\hline tłum. filologiczne: & $\begin{array}{l}\text { Kiedy, jak słońce, myśl zapłonie nad świa- } \\
\text { tem } \\
\text { Człowiecza senna i mętna woda } \\
\text { W potok bystry nagle się zakłębić } \\
\text { I w dal serdeczną unosi się ona. } \\
\text { Dusza jak wicher dumnie mknie nad prze- } \\
\text { paścią }\end{array}$ \\
\hline
\end{tabular}

Zauważmy widoczne w propozycji rosyjskiej tłumaczki zmiany w stosunku do oryginału. Asnyk pisze o nagle jaśniejącej wielkiej myśli, natomiast Griniewska o myśli, która zajaśnieje nad światem jak słońce. W polskim wierszu myśl porywa za sobą mętną falę ludzi, w rosyjskim tekście fala jest nie tylko mętna, ale również senna. W pierwowzorze myśl ma burzliwy prąd i niesie ludzką falę poprzez dzieje, a w przekładzie fala nagle kłębi się w potok i niesie się w dal. W tym miejscu pojawia się też redukcja. W oryginale fala niesie się ku szczęściu, prawdzie, zwycięstwu i chwale, a w tłumaczeniu płynie tylko w dal. Wreszcie, kiedy Asnyk pisze o olbrzymiejącej ludzkiej piersi, Griniewska prezentuje swojemu odbiorcy duszę, która mknie jak wicher nad przepaścią.

Innym tekstem, do którego się odwołamy, jest motto do Na skalnym Podhalu Kazimierza Przerwy-Tetmajera, rozpoczynające się incipitem Ku mej ko- 
łysce... (Przerwa-Tetmajer: online). Griniewska nadała mu tytuł Tom вemep (Przerwa-Tetmajer, tłum. Griniewska: online), czyli „tamten wiatr”, rozbudowała wersy, liczące po 9-10 sylab aż do 11-12, przekonstruowała wiersz, nadając mu formę dwustrofowego, czterostopowego amfibrachu $\mathrm{z}$ kataleksą w wersach zakończonych spadkiem oksytonicznym. Ponadto tłumaczka, podobnie jak w innych przekładach, dodała do swego tekstu kilka epitetów:

- otarty o orle skrzydła wiatr: „Ku mej kołysce leciał od Tatr / o skrzydła orle otarty wiatr", w jej wariancie leci pieszcząc orle skrzydła i kołuje w tłumie siwych obłoków: „Тот ветер, что, крылья лаская орлов, / Крутился в громаде седых облаков";

- wiatr zamiast wlewać w duszę lirycznego „ja” tęsknotę za orlą swobodą, przynosi mu od podniebnych ptaków nierozumne pragnienie orlej wolności: „От птиц поднебесных мне ветер принес / Безумную жажду свободы орлиной”;

- wiatr ten przynosi zadumę limb, które - objęte ciszą - kołyszą się w pustce, jednak w przekładzie przynosi on lirycznemu ,ja” od jodły, rosnącej nad otchłanią, rój czułych, wielkich, niespełnionych marzeń.

Warto dodać, że Griniewska zatarła też charakterystyczny kulturowy element, jakim są Tatry, i zneutralizowała polskie limby, które zastąpiła jodłami.

Nie jest to odosobnione działanie tłumaczki. Neutralizacja nacechowania kulturowego pojawia się też w jej wersji wiersza Rosła kalina Teofila Lenartowicza. Zniknęło z niego polskie imię Jaś: „Jasio fujarki kręcił z wierzbiny”, „pod czarny krzyżyk Jasia złożono” (Lenartowicz: online), a na jego miejscu pojawiły się pozbawione kolorytu narodowego określenia "pastuch”: „свивал / Пастух бледнолицый из ивы свирели” і „śpiewak” „в могилу певца закопали" (Lenartowicz, tłum. Griniewska: online).

\section{Jednostka jako przyczynek do badań}

Spróbujmy podsumować zaprezentowane wyżej rozważania. Wprawdzie nie przeanalizowaliśmy wszystkich translatorskich prac Izabelli Griniewskiej, jednak przeprowadzone badania pozwalają dokonać pewnych uogólnień i wyciągnąć wnioski.

Po pierwsze, wnioski te odnoszą się do oddziaływania epoki (srebrnego wieku) i dominujących w danych czasach tendencji literackich na działania tłumaczki. W przypadku Griniewskiej dotyczy to przede wszystkim związku symbolizmu z mistycyzmem i romantyzmem. Niewątpliwie wpłynęło to na wybór materiału do tłumaczenia. Stąd właśnie obserwowana seria prze- 
kładów, którą rozpoczyna Mickiewicz, a zamykają przedstawiciele Młodej Polski. Romantyczne motywy obecne w tej poezji odpowiadały koncepcjom najważniejszych nurtów i szkół literackich rosyjskiego srebrnego wieku.

Po drugie, na ukształtowanie „romantyzującego” charakteru działalności translatorskiej, jaką reprezentowała poetka, złożyły się także znane jej, ścierające się na początku XX stulecia koncepcje wiernego i wolnego (twórczego) przekładu, a także odwoływanie się tego ostatniego do tradycji romantyzmu, co możemy obserwować również w wypowiedziach współczesnych badaczy. Przytoczmy w tym miejscu konstatację Bogny Opolskiej-Kokoszki na temat przekładu idealnego, która pochodzi z końca lat 80. ubiegłego stulecia:

La traduction idéale est celle qui rend identique concept produit dans l'esprit de l'auteur - émetteur avec celui du traducteur - intermédiaire et celu idu destinataire ${ }^{12}$ (Opolska-Kokoszka 1987: 20).

Myśli tej komentować nie będę; cytat obrazuje jedynie poglądy na przekład, które znajdujemy już w powstałej pod koniec XVIII wieku koncepcji trójpodziału tłumaczeń Novalisa na gramatyczne, przetwarzające i mityczne, a także w marzeniu filozofa o tłumaczeniach mitycznych, o czym pisał:

...są tłumaczeniami w najwyższym stylu. Przedstawiają one czysty, doskonały charakter indywidualnego dzieła sztuki. Nie oddają nam one rzeczywistego dzieła sztuki, lecz jego ideał. Sądzę jednak, że nie istnieje jeszcze żaden pełny wzór takiego tłumaczenia (Novalis 1984: 105-106).

Stosując się do tej koncepcji, poszukiwania Griniewskiej można uznać albo za mityczne (dążące do mitycznych), albo też za tłumaczenia przetwarzające, do których:

...jeśli mają być prawdziwe, potrzeba najwyższego poetyckiego ducha. [...] Prawdziwy tłumacz tego rodzaju faktycznie sam musi być poetą poety i umieć pozwolić mu mówić zgodnie z ideą zarówno własną, jak i samego poety (Novalis 1984: 106).

Po trzecie, nie do przecenienia jest zainteresowanie Griniewskiej filozofią i religiami Wschodu, a przede wszystkim jej fascynacja bahaizmem, głoszącym hasła jedności, równości i wyzwolenia od tyranii.

12 „Tłumaczenie idealne to takie, które w świadomości tłumacza-pośrednika oraz odbiorcy docelowego odtwarza koncepcję utworu identyczną z powstałą w świadomości autora-nadawcy” tłum. A.B. 
Wszystko to musiało prowadzić do wyboru strategii translatorskiej zorientowanej z jednej strony na przekaz tego, co w pierwowzorze najbardziej romantyczne, a $\mathrm{z}$ drugiej na prezentację własnych twórczych wyborów przekładowych. Romantyczna wolność stała się też wolnością tłumacza.

Potwierdzeniem dla tej konstatacji stały się dla nas analizowane w prezentowanym studium teksty, zarówno polskie oryginały, jak i ich rosyjskie odpowiedniki. Przekłady te nie zawsze odbiegają od tekstów źródłowych na poziomie makrotekstu, na przykład w realizacji wiersza Mickiewicza nie zaobserwowano znaczących odstępstw. Ale już w wariantach poezji Asnyka i pozostałych poetów odstępstw jest więcej i to nie tylko w sferze mikro, a niektóre rosyjskie wersje tak wyraźnie odbiegają od oryginałów, że czytając docelowy tekst, trudno domyślić się pierwowzoru. Tak było w przypadku tłumaczenia Idź dalej. Wypada jednak odnotować, że wspomnianych odstępstw od oryginału nie można uznać za błędy językowe, ponieważ tłumaczka dobrze znała język polski i swobodnie się nim posługiwała.

Trzeba też przyznać, że we wszystkich tłumaczeniach Griniewskiej obserwujemy wzmocnienie tekstu akcentami „romantycznymi”, przy czym pojawia się w nich cały „romantyczny arsenał poetycki”. Z jednej strony są to uczucia i sceny w „tonacji minorowej”: rozpacz, samotność, ból, śmierć, które łączą się z obrazem nocy, przepaści, ciężaru, drogi, ciemności, a z drugiej rekwizyty, które mogą być też wyrazem porywów romantycznej duszy: strzały, serce, dusza, burza, kwiaty, które rozkwitają i więdną.

Mamy tu więc do czynienia $\mathrm{z}$ adaptacją formalną, sprowadzającą oryginał do postaci wiersza sylabotonicznego, a jednocześnie $z$ transformacją tekstu, ukierunkowaną na wyeksponowanie romantycznych wartości obecnych $\mathrm{w}$ tłumaczonych utworach. Zarówno naturalizacja formy, jak i wzmocnienie semantyki są zgodne z tradycją translacji, jaka ukształtowała się w Rosji i w Związku Radzieckim na początku XX stulecia oraz z dominantami literackimi epoki srebrnego wieku, kiedy żyła i tworzyła Izabella Griniewska.

W tak krótkiej, ograniczonej limitem czasu bądź limitem wydawniczym wypowiedzi nie można rozstrzygnąć czy poruszyć wszystkich problemów, które zauważamy w rozpatrywanym materiale. Zawsze pozostanie coś jeszcze, jakiś fakt godny uwagi, której mu jednak nie poświęcono czy też poświęcono jej zbyt mało, coś niedopowiedzianego, a może wątpliwość, której nie udało się rozwiać. Zwykle pojawia się też pytanie o znaczenie wskazanego problemu.

Niniejsze rozważania również pozostawiają margines spraw nierozpatrzonych i pytań nierozstrzygniętych. Jestem jednak przekonana o potrzebie przypominania dokonań dawnych tłumaczy i rozpatrywania ich pracy w kontekście danej epoki, ponieważ pomaga to budować ciągłość badań z za- 
kresu teorii i praktyki tłumaczenia. Myślę też, że zwrócenie uwagi na kontekst historyczny, a przede wszystkim na dominanty literackie rozpatrywanej epoki pozwala lepiej zrozumieć ewolucję, jaka dokonała się na polu translacji na przestrzeni ostatniego stulecia, a jednocześnie zaobserwować to, co w sztuce przekładu niezmienne.

W tym właśnie kontekście próbowałam wskrzesić w prezentowanym studium pamięć o jednej z wielu zapomnianych tłumaczek, osadzając twórczość Griniewskiej w tradycji epoki oraz przekonań światopoglądowych i traktując jej działalność translatorską jako jedno z ogniw diachronicznie widzianego łańcucha myśli przekładoznawczej.

\section{Literatura}

Asnyk, A., Dwie fazy, https://wolnelektury.pl/media/book/pdf/asnyk-dwie-fazy.pdf (dostęp: 11 marca 2016 r.).

Asnyk, A., Idź dalej..., http://literat.ug.edu.pl/asnyk/017.htm (dostęp: 11 marca 2016 r.).

Asnyk, А., Две фазаз, tłum. И. Гриневская, http://www.vekperevoda. com/1855/grinev.htm (dostęp: 11 marca 2016 r.).

Asnyk, А., Иду я с ношею..., tłum. И. Гриневская, http://www.vekperevoda. com/1855/grinev.htm (dostęp: 11 marca 2016 r.).

Hermans, T., 1985, „Introduction. Translation Studies a New Paradigm”, [w:] The Manipulation of Literature Studies in Literary Translation, T. Hermans (red.), London: Croom Helm Ltd.

Isabella Grinevskaya, [w:] Wikipedia, https://en.wikipedia.org/wiki/Isabella_Grinevskaya (dostęp: 11 marca 2016 r.).

Kielar, B. Z., 1988, Tłumaczenie i koncepcje translatoryczne, Warszawa.

Lefevere, A., 1983, Literature, Comparative and Translated, „Babel”, nr 2, s. 74.

Lenartowicz, T., Rosła kalina, http://literat.ug.edu.pl/teofil/004.htm (dostęp: 11 marca 2016 r.).

Lenartowicz, Т., Калина, tłum. И. Гриневская, http://www.vekperevoda. com/1855/grinev.htm (dostęp: 11 marca 2016 r.).

Mickiewicz, A., Polały się łzy me..., https://wolnelektury.pl/katalog/lektura/ liryki-lozanskie-polaly-sie-lzy.html (dostęp: 11 marca 2016 r.).

Mickiewicz, А., Слезы, tłum. И. Гриневская, http://www.vekperevoda. com/1855/grinev.htm (dostęp: 11 marca 2016 r.).

Novalis, 1984, Uczniowie z Sais. Proza filozoficzna - Studia - Fragmenty, thum. J. Prokopiuk, Warszawa: Czytelnik. 
Opolska-Kokoszka, B., 1987, Pour un modèle interdisciplinaires de la traduction, „Babel”, nr 1, s. 18-22.

Przerwa-Tetmajer, K., Ku mej kołysce... - Motto do Na skalnym Podhalu, [...] http://literat.ug.edu.pl/ literat/podhal/index.htm (dostęp: 11 marca 2016 r.).

Przerwa-Tetmajer, К., Тот ветер, tłum. И. Гриневская, http://www.vekperevoda.com/1855/grinev.htm (dostęp: 11 marca 2016 r.).

Przyboś, J., 1998, Czytając Mickiewicza, Warszawa: Oficyna Wydawnicza "Rytm".

Rarot, H., 2012, Fenomen polikulturowości: Izabela Gryniewska, [w:] Белорусский сборник: статьи и материаль по истории и культуре Белоруссии, Р. С. Мотульский, В. В. Антонов, Н. В. Николаев (red.), отв. сост. Н. В. Николаев, Санкт-Петербург: Санкт-Петербургская ассоциация белорусистов, t. 5, s. 172-179.

Азов, А. Г., 2012, К истории теории перевода в Советском Союзе. Проблема реалистического перевода, „Логос”, nr 3, s. 131-152, http:// www.intelros.ru/ readroom/logos/y3-2012/18015-k-istorii-teorii-pere voda-v-sovetskom-soyuze-problema-realisticheskogo-perevoda.html (dostęp: 11 marca 2016 r.).

Варламов, А. Н., 2008, Александр Гринн, Москва: Молодая гвардия.

Гаспаров, М. Л., 1971, „Брюсов и буквализм: по неизданным материалам к переводу «Энеиды»”, „Мастерство перевода”, zesz. 8, s. 90-128.

Гаспаров, М. Л., 2000, „О книге С. В. Шервинского”, [w:] Трагедии в переводе С. В. Шервинского, Томск: Водолей, s. 4.

Гачечиладзе, Г. Р., 1973, „Теория художественного перевода и подготовка молодых переводчиков", [w:] Художественный перевод. Взаимодействие и взаимообонащение литератур. Сборник статей, В. Х. Ганиев i in. (red.), Ереван: Изд. Ереванского ун-та, s. 106-124.

Гриневская, И. А., 1900-1902, Я среди людей мира или мой энииклопедический словарь, Druk zgodny z oryginałem (РГАЛИ, Ф. 125, Оп. 1, Ед. Хр.22, Л. 81-84), [w:] Фундаментальная электронная библиотека „Русская литература и фольклор”, http://feb-web.ru/feb/rosarc/ rae/rae-5893.htm (dostęp: 11 marca 2016 r.).

Кольцова-Царева, Е., 2015, Мемориал. Гриневская Изабелла 1864-1942, https://www.proza.ru/2015/05/29/1842 (dostęp: 11 marca 2016 r.).

Ланчиков, В. К., 2009, „Развитие художественного перевода в России как эволюция функциональной установки", [w:] Вестник Нижегородского государственного университета им. Н.А. Добролюбова, zesz. 4. Лингвистика и межуельтурная коммуникация, 
163-172, http://www.thinkaloud.ru/sciencelr.html (dostęp: 11 marca 2016 r.).

Леоненко, Е. В., 2015, Изабелла Гриневская: биография и литературное творчество. Обоснование темы, http://www.pushkinskijdom.ru/Default.aspx?tabid=11240 (dostęp: 11 marca 2016 r.).

Лифшиц, Ю. И., Между Сциллой и Харибдой. «Синий извет» Николоза Бараташвили в переводе Бориса Пастернака, http://www.poezia.ru/ works/116146 (dostęp: 11 marca 2016 r.).

Сергеева-Клятис, А. Ю., 2005, Искусство перевода: Борис Пастернак, „Литература”, nr 13, s. 33-37, http://lit.1september.ru/article.php?ID= 200501314 (dostęp: 11 marca 2016 r.).

Степура, С. Н., 2011, Специфика перевода эпохи модернизма в России в 20-30-е годы ХХ века, „Молодой ученый”, nr 10, t. 2, s. 42-47.

Чач, Е. А., 2012, Ориентализм в общественном и художественном сознании Серебрянного века. Autoreferat rozprawy doktorskiej, СанктПетербург: Санкт-Петербургский государственный университет, https://disser.spbu.ru/files/ disser/\%7Bzashiti_disser__id\%7D/avtoref-Chach.pdf (dostęp: 11 marca 2016 r.).

\section{Dominants of the Silver Age period: Isabella Grinevskaya as the translator of Polish poetry}

Summary

The article focuses on the analysis of translations of Polish poetry made by Isabella Grinevskaya who was active in the late nineteenth and early twentieth centuries. Her translations have been considered in the context of the literary dominants of the Silver Age period as well as principles, views and discourses of translation valid at that time. It also concentrates on Grinevskaya's religious and philosophical interests, which influenced her choices in translation. Attempts were also undertaken to demonstrate the art of Grinevskaya's translation, regardless of the historical period in which she created her works, as one of the links within Translation Studies.

Keywords: Isabella Grinevskaya, Silver Age, translation, poetry

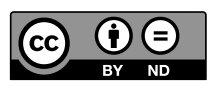


